\title{
The soteriological meaning of Jesus' death in Luke-Acts. A survey of possibilities
}

Hermie C van Zyl

Dept of New Testament, University of the Free State

\section{ABSTRACT \\ The soteriological meaning of Jesus' death in Luke-Acts. A survey of possibilities}

The portrayal of Jesus' death in Luke-Acts remains an intriguing issue. Ever since the rise of critical scholarship it has become the standard view that Luke does not accord salvific meaning to the death of Jesus, but rather stresses the exaltation of Jesus as the zenith of his soteriology. In light of this standard view, this article investigates the question whether the soteriological meaning of Jesus' death has received more attention in recent literature. The finding is that in the main scholarship still favours the exaltation of Jesus as the soteriological zenith. However, it is also clear that there is a tendency to move away from a bland underestimation of Jesus' death towards a more balanced view in which Jesus' death acquires a more positive soteriological meaning in and of itself.

\section{STATING THE PROBLEM}

Ever since the rise of critical scholarship the peculiar position of Luke-Acts vis-à-vis Mark, Matthew, John and Paul concerning the portrayal of the death of Jesus has been noted ${ }^{1}$. Although the matter was addressed by earlier scholars, it was the work of the early redaction critics that brought the issue to a head (Richard 1990:126). These scholars are generally in agreement that Luke has greatly reduced the salvific sense of the death of Jesus. Usually the following data are lined up in support of this view:

(a) In Luke 22:27 Luke omits the I utr r on-logion of Mark 10:45 (taken over almost verbatim by Matthew in 20:28) which has Jesus saying that the Son of Man came to give his life as a "ransom for many". As a matter of fact, Luke altogether alters the Son of Man saying ${ }^{2}$ by emphasising only the

\footnotetext{
${ }^{1}$ For a fine overview of the problem in the history of research, see Pilgrim 1971:1-34. For an equally commendable and more updated survey, see Herrick 1997.

2 To say that Luke "altogether alters the Son of Man saying” implies that Luke used and edited Mark 10:(41-)45, as indeed some scholars believe (cf Grundmann 1969:401; Matera 1985:472). However others are of the opinion that Luke did not edit Mark at this point, but used a non-Markan, pre-Lukan source for 22:24-27 (so Green 1988:46; Carroll
} 
serving aspect of Jesus' ministry (cf Goppelt 1978:618).

(b) There are only two passages in which Luke explicitly refers to the saving significance of Jesus' death, namely Luke 22:19-20, the so-called institution of the Lord's Supper ("This is my body, which is given for you" ... "This cup is ... the new covenant in my blood”), and Acts 20:28 which mentions the church as having been obtained by the blood of Jesus.

(c) Apart from Luke 22:19-20 and Acts 20:28 being the only passages explicitly pointing to the redemptive meaning of Jesus' death in Luke-Acts, they are also regarded as dubious witnesses. First of all they are text critically uncertain. Luke 22:19-20 is widely held to be the most problematic one of the two. Although the UBS Greek Text accepts Luke 22:19b-20 as authentic, it assigns it a B rating in its first and fourth editions, and only a C rating in its third edition, the latter rating followed by Metzger in his textual commentary (1975:173). The issue at stake is precisely the institutionary words of the Lord's Supper: whereas the majority of witnesses do contain these words, the Western text type omits them ${ }^{3}$. As far as Acts 20:28 is concerned, the verse as such is not at risk, but the problems are no less intriguing ${ }^{4}$. Secondly, even if one accepts these two passages to be authentic,

\& Green 1995:12; theory already introduced by H Schürmann, Jesu Abschiedsrede, 6399, in 1957). See also footnote 24 for further discussion.

${ }^{3}$ An instance of a Western non-interpolation, according to the minority view among the members of the UBS Committee that compiled the UBS Greek Text. The point is that some Committee members regarded the omission as the original reading. For a complete and balanced discussion of the text critical problems involved, see Metzger 1975:173177.

${ }^{4}$ It is generally accepted that qeot, in the phrase thn ekklhsian tou 'qeou', and not kurio (as some witnesses suggest), is the original reading. But if so, a conceptual problem arises when the following phrase seemingly speaks of "God's own blood" (dia ; t ou 'a ingat o t ou 'idiou). But should idiou be taken to mean "God's own blood" or "the blood of God's own (Son)"? Some scholars prefer the latter, because i di $0 \sim$ is seen as an abbreviated term of endearment for "God's own Son" (so Metzger 1975:481). This is perhaps the easiest way to solve the conceptual awkwardness arising from the translation "his (God's) own blood" in the sentence ... poimainein thn ekkl hs i an tou 'qeou,' $h$ k periepoinsato dia; t ou ainnat o tou'idiou. However, as Pilgrim (1971:170) has pointed out, perhaps this is too easy a solution. It may very well be that the two phrases, "the church of God" having been "obtained through his own blood" ("own blood" grammatically referring to its antecedent “God”), were inadvertently combined without Luke or his source being aware of the theological problem it caused in terms of the "patri-passion" theories of later times. The implication of this solution, though, is still that in the mind of the author "own blood" refers to the death of Jesus and not to the passion of God. So even if it is accepted that the two phrases were inadvertently 
it still leaves us with the problem that they appear to be mere mechanical repetitions of the church tradition about the saving significance of Jesus' death (cf Kodell 1979:223). It does not seem as though Luke integrates these verses into his theology (O'Toole 2000:336). Nowhere else in Acts does the blood of Jesus appear as having saving significance. And Luke 22:19b-20 contains several linguistic features that are non-Lukan (Metzger 1975:176; see Green 1990:4 for particulars). This ties in with another observation, that in Luke 22:19-20 Luke seems to have mechanically introduced the order and wording known to him from the liturgical practice among the Pauline churches. (Lk 22:19-20 closely resembles the Pauline tradition found in 1 Cor 11:23-26.) The introduction of the Pauline tradition is visible in the fact that Luke 22:17-20 displays the peculiar order of "cup-bread-cup" at the Last Supper as opposed to Mark's simpler "bread-cup” order. So it could be that Luke, after having mentioned the distribution of the cup among the disciples in 22:17-18, mechanically introduced the Pauline tradition which resulted in the order of cup-bread-cup in Luke 22:17-20 (cf Metzger 1975:176-177) $)^{5}$. Thus, although Luke 22:19-20 does portray Jesus' sacrificial self-offering by which the covenant is established, its importance for Luke seems to be minimised because the sacrificial notion is not borne out when compared to Luke's own distinctive presentation of the cross elsewhere in his writings (cf Pilgrim 1971:217).

(d) Luke does not link the community meals in Acts ("the breaking of the bread" as he refers to them) to the Lord's Supper, as Paul does it in 1 Corinthians 11:17-34. Therefore Green, having surveyed the occurrences of the community meals in Acts, concludes that these meals admittedly were not mere incidents of sharing food, but "nor do they appear to have (had) any specifically eucharistic or sacramental quality either” (1990:6). Rather they are portrayed as directly related to the post-resurrection meal(s) shared with Jesus (Lk 24:30) and among the first Christians in Jerusalem (Acts ). For Luke then the importance of the Last Supper lay in fellowship, in anticipation of the fellowship meals which were to come where the joyous aspect of the resurrection was in focus and not so much the commemoration

combined, with idiou grammatically referring to God's blood, materially it boils down to the same as if idiou is taken as a substantive for the Son.

${ }^{5}$ Ehrman (1991) contends that it was not Luke that introduced the Pauline tradition, but second century scribes, out of orthodox concerns, i e, to give support to the salvific meaning of the death of Jesus. Thus, for Ehrman this is an instance of the "orthodox corruption of Scripture”. 
of the death of Jesus ${ }^{6}$.

(e) Even though Luke makes extensive use of the Suffering Servant motif of Is 52-53 in the Gospel and Acts, he quotes (or alludes to) it in such a manner that the parts dealing with the vicarious death of the Servant ostensibly are left out (e g in Acts 8:32-33 Is 53:7-8 is quoted, but the words referring to the expiatory meaning of the Servant's suffering are omitted) (cf Lohse 1963:189; Hooker 1998:91-92; Jones 1984:153).

(f) In the speeches of Acts the forgiveness of sins is nowhere linked to the death of Jesus, but is based on repentance, conversion, the resurrection of Christ, and faith in Christ $(2: 38 ; 3: 19 ; 5: 31 ; 10: 41 ; 13: 38)$ (cf Du Plessis 1994:535; Kodell 1979:222; Lohse 1963:188).

The net result of the above survey is that at first glance the soteriological import of the death of Jesus in the Lukan double work is not foregrounded. One finds it difficult to describe Jesus' death in Luke-Acts by means of expressions such as "redemption of sinners" or "expiation of sins", the traditional interpretation of Jesus' death well-known from other parts of the New Testament. Thus the task of the following investigation is to examine whether, and if so how, the death of Jesus in Luke-Acts has soteriological meaning. In order to do this, the full spectrum of how Jesus' death is presented by Luke needs to be surveyed. In light of the scholarly debate it must be said at the outset that Jesus' death in Luke-Acts cannot be summed up in a single monolithic view, but is best described in terms of different perspectives. Consequently my investigation will consist of a survey of the most prominent perspectives today on the death of Jesus in Luke-Acts . As will become clear, some of these perspectives are closely linked to specific scholars, others are more generally held opinions within Lukan scholarship. Finally I shall present a brief appraisal.

\section{PERSPECTIVES ON THE DEATH OF JESUS IN LUKE-ACTS}

When trying to determine the precise relationship between Jesus' death and the salvation of people, it needs to be said right at the beginning that salvation in Luke-Acts is rather the outcome of the entire life story of Jesus:

\footnotetext{
${ }^{6}$ Du Plessis (1994:527-528) makes much of the Last Supper as part of Luke's penchant for portraying Jesus as enjoying table companionship with his disciples and with a variety of other people to put across his teaching (see Lk 5:29-39; 7:36-50; 11:37-52; 14:1-24). Thus, according to Du Plessis, at the Last Supper the emphasis is not on this meal's sacramental character, but on its quality as the final opportunity Jesus uses to instruct his disciples about the spiritual legacy He is leaving them. It takes the form of a farewell speech in which Jesus forms a pact, a covenant, with them to continue his teaching.
} 
his coming, public ministry, death, resurrection, position at the right hand of God, and the outpouring of the Holy Spirit (cf Carroll \& Green 1995:267268; Richard 1990:132). It is only within this broader picture that the soteriological meaning of the death of Jesus becomes apparent and can be adequately understood, as will be described by the following perspectives.

\subsection{The death of Jesus as divine necessity}

While it is true that the explicit salvific interpretation of the death of Jesus is not conspicuous in Luke (except in the texts mentioned above) it remains equally true that Luke makes the strongest possible statement about the central place the death of Jesus occupies in salvation history (Green 1990:12; 1992:159). We can refer to the many times that his death is viewed as a divine necessity: "the Christ must (dei) suffer" (cf Lk 24:26) ${ }^{7}$. The original source of Jesus' death being described as "necessary" (dei ) is Mark 8:31, but Luke has taken it over and expanded its use, so that it can be regarded as a characteristically Lukan feature (Pilgrim 1971:372). In addition to the Markan parallel (8:31) in Luke 9:22 it occurs in Luke 13:33; 17:25; 22:37; 24:7,26,44 and Acts 17:3, all special Lukan traditions or redactions. In Luke 24:25,27,46 dei is not used, but the same thought occurs. What is of particular significance in almost all of these verses is that the death of Jesus is seen as the fulfilment of Scripture. Death does not befall Jesus by accident, but by divine design. Jesus' death has a preordained place in the grand design of God's salvation plan. His death is not only the result of evil people's planning, but ultimately lies in the fact that God wills it and lays it as a calling upon Jesus. But apart from Jesus' death being the fulfilment of Scripture and thus of divine planning, it is also evident that Jesus had foreknowledge of his death and willingly took this suffering upon him, as is shown in Luke 9:44,51; 13:33; 18:31-33. In this regard 9:51 is significant. It depicts Jesus as "having made a firm resolve" (t $0 ;$ p r 0 s wp on esthrisen) to go to Jerusalem because "the days of his taking up drew near". In sum we can say that while the concept of the necessity of Jesus' passion is taken over from Mark, the particular emphasis it receives in Luke is without parallel in the Synoptic Gospels. It is clear that Luke wants to create the impression that the death of Jesus is no accident but fits divine design; furthermore, that Jesus is in full control of all the events of his passion (Green 1992:160).

\footnotetext{
${ }^{7}$ The whole concept of divine necessity would not have been out of touch with general beliefs in ancient times about history being controlled by divine necessity. In the Greek world it was viewed as a "neutral" force, but in Israel as deriving from the personal will of God who is a living person (Talbert 1984a:96).
} 
The question remaining is what exactly Luke means by assigning Jesus' death to the category of divine necessity. Divine necessity for what purpose? For atonement of sins? It almost has become convention in Lukan scholarship to answer this question in the negative. The argument is constantly put forward that even though Luke has a propensity for exploiting Is 52-53 for the death of Jesus (see further sec 2.3 below) - the one Old Testament passage that could have been utilised to interpret the death of Jesus in terms of vicarious suffering - this is not done by Luke (cf Kodell 1979:222). Yes, Luke does interpret portions of Is 52-53 Christologically (Pilgrim 1971:374), but the emphasis is not on the suffering of Jesus as atonement of sins (Williams 1975:224). Rather the death of Jesus is associated with the humiliation which Jesus suffers at the hand of people, as in Acts 8:32-33 (so Decock 1981; Jones 1984:153). ${ }^{8}$. In that sense his death was necessary, because it fulfils the longstanding tradition of the true prophets of Israel who experienced their message and ministry as being rejected by the people (cf Jesus' referring to this tradition in Lk 13:33). The rejection is necessary in order for God to eventually vindicate the life and message of his suffering servants. In this world God's wise and obedient people will always suffer at the hand of evil people. In this sense it is a divine necessity, not because God ordains it, but because people do this to the righteous. "It is a suffering that originates not with God, but with men who oppose God" (Pilgrim 1971:375). Thus it is necessary for the righteous to suffer so that the truth of their lives may be vindicated by God. It is along these lines - rejection vs vindication - that the divine necessity of Jesus' death is viewed by Luke. Says Pilgrim (1971:376): “At the heart of Luke's conception of the cross ... is not its necessity as a means of atonement, but its necessity as an act of suffering obedience to the will of God, which finds its vindication in the resurrection and exaltation to glory."

In the light of the above, the least we can say is that the theme of Jesus' death is not less important to Luke; on the contrary, it receives much emphasis. But apparently it is viewed from a perspective that differs from those of Mark and Paul (Richard 1990:127-128). Exactly how different will become clear from the subsequent sections.

\footnotetext{
${ }^{8}$ Although the aspect of humiliation is certainly important in Luke's quoting of Is 53:7-8 in Acts 8:32-33, reference to the meaning of the death of Jesus as such cannot be ruled out here. In this regard Parsons (1998:115-119) has drawn our attention to the intertextual links between Acts 8:32-33 and Lk 24:25-27,44-47. The latter verses supply the theological exposition of Christ's suffering that scholars usually claim is missing from Acts 8:32-33.
} 


\subsection{The death of Jesus as a prelude to his exaltation?}

Sometimes the difference between Luke's and Paul's view of the death of Jesus is described as follows: Paul sees salvation as being available thanks to the death of Jesus, but Luke in spite of his death (cf Van der Kooi 1997:286287). This ties in closely with the previous section about Luke viewing the death of Jesus as part of God's salvation history plan. We may call this the apocalyptic model ${ }^{9}$ of salvation, where death in itself does not constitute salvation, but nevertheless forms a necessary part of it (Van der Kooi 1997:285-286). The Lukan strategy of salvation history creates an overarching framework in which even the death of the Messiah can find a place. But according to this view his death in itself does not cause salvation; rather it is seen as a prelude to some sort to the salvation to be brought about by his exaltation (Kodell 1979:225), the latter comprising Jesus' resurrection, ascension, sitting at the right hand of God, and the outpouring of the Holy Spirit. In this view the focus in Luke-Acts is not so much on the death of Jesus as on his exaltation. It is the latter that constitutes salvation. Thus the Lukan narrative creates a theodicy of some kind. It becomes a justification of God's way of suffering and glorification with Israel, Jesus and the early church (Tiede 1991:301ff). Viewed against a wider perspective one can almost say that structurally the Christology of the Lukan double work is coined according to the same thought pattern as found in Phlp 2:6-11, where Jesus is presented as the pre-existent who suffers death and is exalted again to the place of honour (so Becker 1990:37).

Luke's emphasis on the exaltation of Jesus is supported by the contrasts in Acts between what the Jews ${ }^{10}$ did to Jesus and what God

\footnotetext{
${ }^{9}$ Van der Kooi (1997:285) also describes six other models of how in the New Testament the death of Jesus may be interpreted, taken over from G Barth. They are: 1. the suffering of the righteous; 2 . death as fate of the prophets; 3 . vicarious suffering for sins; 4 . ransom; 5. participation in Christ's death; 6. Jesus' death as victory over the power of death.

${ }^{10}$ By "Jews" one should in fact be mentioning the Jewish leaders by name. The latter, especially the chief priests, are the main culprits in killing Jesus - at least according to the Luke's Gospel. Tyson (1986) has convincingly argued that whereas the Pharisees play an ambivalent role towards Jesus and are excluded from the events leading up to his death, the chief priests are isolated as the main culprits (cf 1986:78). The Pharisees' opposition to Jesus is associated with issues pertaining to the law, whereas that of the chief priests is related to issues concerning the centrality of Jerusalem and the temple. When we turn to Acts, the picture changes. Chance (1991:71) has pointed out that in the speeches of Acts the Jewish people of Jerusalem, and not only the leaders, are equally held responsible for Jesus' death. Chance explains this discrepancy between the Gospel and Acts as that passive non-resistance in the face of evil (the Jewish crowds) is just as reprehensible as
} 
eventually did. In Acts 2:36 and 3:13-15 Peter on two occasions castigates the Jews for having rejected Jesus, since it is precisely this Jesus, the "Author of life" (ajchgo; th $\sim$ zwh $\sim$, 3:15), whom they had rejected and crucified, that God vindicated by raising Him from the dead and by making Him Lord and Christ (kai kurio ... kai; crist o t, 2:36 ${ }^{11}$ ). In Acts 5:30-31 we find a similar contrast, but this time Jesus is called "Leader and Saviour" (ajchgo; kai;swthr). Important here is the title "saviour", and that the notion of repentance and forgiveness of sins, and thus salvation, is attached to the exalted Christ. As the exalted one He is on a par with Yahweh of the Old Testament. Just as people under the old covenant could call on the Name of Yahweh to be saved ( $\mathrm{Jl} 2: 32$ ), they can do so now by calling on the Name of Jesus (Acts 2:21; 10:43; cf Lk 24:47). It is precisely through the fact that Jesus was raised and seated at the right hand of God that He assumed the status and right to forgive sins. To this the outpouring of the Holy Spirit should be added too. For Luke salvation is not only realised through the forgiveness of sins, but also in the receiving of the Holy Spirit (see Acts 2:38; 9:17; 10:43-44; 11:15-17). As the exalted Christ, Jesus has received the Spirit and now has the authority to administer the giving of the Holy Spirit (Green 1990:10).

That Luke joined salvation to the exaltation of Jesus is also implied in the somber scene of the two disciples en route to the town of Emmaus (Lk 24:13-35). By mentioning their sadness (v17), Luke indicates that the death of Jesus was a big disappointment to the disciples. They had such high hopes that Jesus would be the one to redeem Israel (v21), but now He was dead. Therefore it is significant that only after their eyes had been opened to see the glorified Jesus, and once they had realised that he was alive and present in their midst, their hearts picked up and the joy returned (cf v32). To this may be objected that there is nothing special about the description of joy; it is only natural that they would be glad at Jesus being alive again. But viewed against the total picture of Luke's interpretation of Jesus' death and

active participation in the evil of killing the Christ of God (the Jewish leaders). But to be held responsible is not the same as being rejected by God. Carlson (1991) concurs with Chance that, according to Luke, the Jewish people are just as guilty of the death of Jesus as the Jewish leaders, but that Luke constantly leaves open the possibility for repentance by the people (Lk 23:48; Acts 2:37).

11 Tiede (1991:305) contends that Acts 2:36 should first be heard as a threat. It ties in with his view that what is at stake in Jesus' death in Luke is a confrontation with God in which God's will is tried. “Those who resist the king's reign (see Lk 19:11-27) or kill the royal heir (Lk 20:9-19) place themselves in grave peril, testing God's forbearance” (Tiede 1991:305). 
exaltation, this incident should be assigned greater significance. It is the fact of Jesus' resurrection, or rather, it is the fact of Jesus being present in their midst, that creates joy and a new sense of well-being among his followers. In this regard Richard (1990:138-152) has shown extensively that it is the abiding presence of Jesus, as a result of the resurrection, which receives the actual focus in Acts . Says Richard (1990:151): "Luke's concern ... is less the resurrection ... than the presence of the risen Lord within the early community .... For Luke Jesus is both the one enthroned at God's right hand and the one who lives and Acts within the community as proclaimer of salvation, directly and through intermediaries."

To conclude this section, it needs to be said that one must guard against relegating the death of Jesus to a position of serving as a mere prelude to the actual saving event, the exaltation of Jesus. This could easily lead, and among some scholars indeed has led, to the conviction that the death of Jesus as such plays no salvific role in Luke-Acts ; it can only be seen as part of the early church's tradition that was repeated, but in itself was a mere empty by-product of the exaltation of Jesus. It is true, the exaltation receives more overt attention by Luke, but recent studies have brought aspects to the fore showing that in Luke-Acts there is much more about Jesus' death than meets the eye. It is to this aspect that I now turn.

\subsection{Jesus as martyr, righteous sufferer and Suffering Servant}

It was Martin Dibelius who first promoted the thesis that we should view Jesus' death as the death of an innocent martyr (cf Karris 1990:71). It was particularly the confession of the centurion in Luke 23:47 about Jesus being dika i 0 , the latter translated as "innocent", in conjunction with the words of the penitent criminal on the cross that he and his fellow robber were being punished justly, but that Jesus had done nothing wrong (af op on epraxen, Lk 23:41), that led to this interpretation. And to this day Dibelius's thesis has won many supporters. It seems to provide a respectable "escape route" from the difficulty of viewing the death of Jesus in Luke-Acts along traditional lines.

It must be admitted that the parallels between the death of Jesus as described in Luke 22-23 and that of the martyrs in Jewish martyrology are striking. Karris (1990:71-72) provides the following corresponding themes from the Martyrdom of Isaiah, Daniel and 3 Maccabees: (a) ConfLICT. The martyr is fighting against the power of Satan and the power of darkness (cf MartIs 4:1-12 // Lk 22:3,53). God is on the side of the martyr, and strengthens him through an angel (cf Dn 3:25; 3 Macc 6:18 // Lk 22:43); (b) INNOCENCE. The innocence of the martyrs and of Jesus is demonstrated 
many times (cf Dn 6:4-5; 3 Macc 3:1-10 // Lk 23:4,14-15,22); (c) ATTITUDE OF THE BYSTANDERS. They mock the martyr (cf MartIs 5:1-11// Lk 23:3539); (d) THE CONDUCT OF THE MARTYR. The martyrs suffer for a cause and are steadfast notwithstanding brutal punishments. They stand in a long tradition of believers who remained faithful to God and did not apostatise from the covenant (cf Van Henten 1989a:157). From the whole picture of Jesus' passion one thing that stands out is his willingness to die, and the dignity with which He faces death; (e) AN EXAMPLE IS SET FOR THE MARTYR'S FOLLOWERS. The martyrs are regarded as the ideal representatives of the Jewish nation (Van Henten 1989a:145). Thus the aim of the martyrdom literature is to support the fellow believers who live under the threat of martyrdom. In Luke 22:31-34,54-62 it is shown how Simon Peter cannot withstand the threats being made against him, and thus not follow the example of his master. But in Acts the suffering of Jesus serves as a strong stimulus for the Christian believers to persevere. The most notable is the description of the martyrdom of Stephen (Acts 7), which is consciously paralleled to the death scene of Jesus.

There are various ways in which meaning may be extracted from Jesus being interpreted as an innocent martyr. One is to say that it elicits feelings of remorse from the reader, particularly the Jews, as well as encouraging repentance (cf Goppelt 1978:618). This can be observed at more that one occasion when Luke hints at remorse among the Jews (the crowd beating their breasts, Luke 23:48; the people gathered at Pentecost being cut to the heart and asking Peter what they should do, Acts 2:37), when the Jewish leaders are being accused of having killed Jesus (Acts $2: 23,36 ; 3: 13,15 ; 4: 10 ; 5: 30)$ or that they were ignorant of the time of God's visitation to save them (Lk 19:44; cf Acts 4:27), and when people are being urged to repent (Acts 2:38; 3:19; 5:31; 8:22; 17:30; 20:21; etc).

Another way of extracting meaning from Jesus being portrayed as a martyr, is by connecting it to his life as patterned on the suffering of the prophets in Old Testament times. Kodell (1979:226-229), drawing on the work of Glöckner ${ }^{12}$, draws our attention to Luke's potrayal of Jesus as a prophet (Lk 24:19). As such He is sent to Jerusalem where He must suffer a prophet's fate (13:33). Kodell couples this with Jesus' lowliness, which is essential to his saving mission. As the lowly one (note his humble birth, Lk 2:7), He carries God's salvation to the lowly and the outcast. This mission ends in the humiliation of unjust suffering and death. But it is precisely this unjust suffering that reveals God's unconditional saving will, when Jesus

${ }^{12}$ R Glöckner, Die Verkündigung des Heils beim Evangelisten Lukas, 1976. 
prays for his executioners (Lk 23:34). Seen thus, Jesus' death has meaning in itself, because it confronts human sinfulness by lowliness. And in God's plan, according to Luke, this is the state needed to receive divine salvation. It is only through self-emptying that one finds upliftment by God. This is true of the life of Jesus, and it serves as a model for humankind.

However true these meanings extracted from Jesus being portrayed as martyr may be in themselves, in recent times voices have gone up challenging the parallels between Jesus' death and those of the martyrs. Karris (1990:72-73) and Green (1992:160-161) have drawn our attention to a few important differences, which cause the parallels to be not all convincing. First, the parallels tend to be formal and not material. For example: if there was a material correspondence between Luke 22:43 and 3 Macc 6:18-21 (the angels coming to the aid of the martyrs), Jesus would never have gone to the cross because the angel would have crushed his enemies. Secondly, many of the prominent features of the martyr literature are missing from Luke, for example the martyr's condemnation of his killers (Jesus does not accuse his tormentors; on the contrary, He prays for them, Lk 23:34), and the horrific details of the killing of the martyrs. Thirdly, although Luke portrays Jesus as in control of his passion, He is not a typical hero; He also struggles with the prospect of death. And finally, the martyrdom parallels fail to read Luke 22-23 in the context of the rest of the Gospel, and therefore fail to account for typical Lukan motifs in the passion narrative, such as Jesus' relationship with his Father, whose plan Jesus is fulfilling on the cross. The simple fact is that the notion of Jesus as martyr does not do justice to the richness of Luke's theology of Jesus' death. In spite of the parallels, and in spite of the fact that the death of the martyrs might have served as a literary stimulus for interpreting the significance of Jesus' death (cf Green 1988:167-169), his death nevertheless transcends the category of martyrdom (Carroll 1990:120).

To go beyond the category of martyrdom we need to focus on Luke's portrayal of Jesus as a righteous man. The background to this concept can be found in the long-standing persecution-and-vindication tradition, an ancient literary form for relaying the message of the vindication of the suffering righteous (Green 1990:19) ${ }^{13}$. The view of Jesus as a righteous man can be substantiated at length, but the following two arguments will suffice. First,

${ }^{13}$ Behind the persecution-vindication motif one needs to see the motif of the righteous as exponent of the group of pious people adhering to the Torah (cf Ruppert 1989). It is precisely because of this devotion to the law that they are persecuted by the enemies of the law. 
the translation of dikai $0 \sim$ in Luke 23:47 in the phrase: "Certainly this man was dikaio ", needs closer scrutiny. Many translations render it as "innocent" because of the surrounding context where Pilate, Herod, the repentant thief, and Joseph of Arimathea say that Jesus is innocent (Lk 23:4,14-15,22,41,50-51) $)^{14}$. But there are good reasons for translating dika i o in this instance by "righteous" (so Karris 1990:69; Green 1990:1921; Matera 1985:479-482). The reasons are: the centurion responds to the awesome phenomena in nature as well as to the manner in which Jesus dies, as described in the preceding verses (v44-46). And on top of that the centurion's cry about Jesus being dikaio is part of his praising God (ejloxazen ton qeom, v47). In light of this one can claim v47 to be a liturgical-soteriological verse and dikaio to be rendered best as "righteous". Second, Luke 23:47 forms part of the larger dika i o -theme in Luke and actually brings it to a climax. The righteousness theme runs through Luke like a golden thread and can be summarised, according to Karris (1990:74), in three brief statements: "In Luke, Jesus is the righteous one of Wis 2:10-5:8. His way of righteousness is opposed to that of the religious leaders who plot his death. Jesus brings the good news of God's justice to the poor and afflicted." Thus Jesus is the embattled righteous one in whom God Himself is on trial. God vindicates Himself and his plan for creation by exalting the crucified one. And it is when the pagan centurion sees God at work in the events surrounding Jesus' death, as well as in the way that Jesus dies, that he acknowledges Jesus as God's righteous one (Karris 1990:75).

The interpretation of Jesus as the righteous one inevitably leads to his being depicted as the Servant of the Lord in terms of Is 52:13-53:12 ${ }^{15}$. One can say that for Luke the Servant of the Lord motif forms something of a substructure for the Christology of Luke-Acts (Green 1990:19) ${ }^{16}$. It is only

14 For an overview of the theme of innocence in the Lukan passion narrative, see Scheffler 1993:135-139.

15 There is a very close link between the figure of the Righteous Sufferer and the Suffering Servant of Isaiah. Says Marcus (1995:214): “The two figures were closely connected; the Suffering Servant figure is probably in its origin a prophetic adaptation of the Righteous Sufferer, and Jewish exegetes tended to amalgamate the two figures.”

${ }^{16}$ When O'Toole (2000:345-346) wraps up his investigation of what Luke achieved through his presentation of Jesus as the Servant of the Lord, he says: "This presentation does belong to Luke's christology and can function as a summary of Jesus' mission." It is therefore hard to agree with Jones's viewpoint (1984:156-159) that the titles "Servant of God", "Son of God" and "Christ" are all synonymous to Luke . For Jones this interchanging of titles shows that Luke had a developed Christology. Also, says Jones, these titles "do not preserve from the earliest Christian community a separate and 
when we adopt an eye for this view that we begin to grasp what Luke tries to put across in his description of Jesus' death. This insight can be developed as follows. First, we need to notice the important intertextual connection between Luke 23:47 and Acts 3:13-14. In the previous paragraph I made out a case for di ka i o in Luke 23:47 to be translated as "righteous". But what is the significance of Jesus being righteous? Acts 3:13-14 provides the necessary background. This text is formulated in such a way that it recalls the conceptual world and language of the Isaianic Servant passage of Is 5253 (Green 1990:20-21). We find it in the following aspects: the language of glorifying, the use of "servant" (pai $\sim$ ), the motif of "handing over", and in the appearance of the term dikaio (the righteous one), the same term applied to Jesus in Luke 23:47. It should not surprise us to find traces of Servant language in Acts 3:13-14, since Luke undeniably is fond of describing Jesus' passion in Servant language ${ }^{17}$. Luke has Jesus quoting Is 53:12 in Luke 22:37 ("And he was counted among the lawless"), a passage unique to Luke among the Gospels, and in Acts 8:32-33 (the incident where Philip found the Ethiopian eunuch reading from Scripture) the suffering of Jesus is depicted using a direct citation from Is 53:7-8. Second, once one is alerted to this predilection of Luke, other references may also be seen in this light $^{18}$. The innocence theme, which is so carefully worked out in Luke 23, is clearly an allusion to the righteousness of the Servant of Yahweh, and that Jesus was silent before Herod is reminiscent of the Servant's refusal to speak in his own defense (Is 53:7). Also, the term ekl ekt o $\forall$ applied to Jesus in Luke 23:35, unique to Luke among the Gospels, is of importance. It recalls the designation of God's Servant in Is 42:1.

What did Luke achieve by casting the passion of Jesus in Servant language? Most scholars are reticent to tie it directly to the notion of atonement of sins. But at least we can say that in doing so Luke kept in balance two seemingly opposing themes: the suffering of God's chosen and righteous one, and his vindication (Green 1990:23-24). By overt and covert references to the Servant passage (Is 52-53) Luke succeeds in laying claim to all of the Servant themes in terms of their applicability to Jesus. This means that it is not only the passion of Jesus which is in view, but his whole life. Thus Luke utilises the Servant language of rejection and vindication to hold

primitive Servant Christology - nor could they, since ... such a Christology did not exist” (:159).

${ }^{17}$ Luke is the only NT writer who quotes Is 53 in connection with Jesus' personal fate (Williams 1975:224).

${ }^{18}$ For a detailed study on Luke's overt and covert references to Servant language, see O'Toole 2000. 
together - and in tension - the twin motifs of Jesus' crucifixion and exaltation. In this regard the seminal text from the Servant passage is Is 53:11, which carries the thought that following the suffering of the righteous one, he will make many righteous. Although the latter is not the full-blown language of exaltation, the idea of vindication is certainly present here. Furthermore, it ties in with another of Luke's overarching themes, namely the reversal of roles (Green 1990:25-28). In the kingdom of God, according to Luke, established roles are being reversed. As early as the magnificat (Lk 1:52), it is promised that the powerful will be brought down from their thrones and the lowly will be lifted up. In the Sermon on the Plain the four beatitudes are kept in balance by the four woes (Lk 6:20-26), a structuring peculiar to Luke. Right through the Gospel it is made clear that Jesus is the Saviour of the disadvantaged. In Acts 14:22 it is spelled out that only through many hardships may we enter the kingdom of God. And finally, nowhere else is the reversal of roles more evident than in the life of Jesus Himself. As God's Servant He has suffered death in order to be exalted and appointed saviour of all.

\subsection{Jesus' death as participation in the chaos at the centre of the world}

The previous section about Jesus' death viewed as the death of a righteous man and as the Suffering Servant of the Lord has already alerted us to the importance of Jesus' death as such in Luke's writings. But this insight may be fleshed out even more when we take two more aspects into consideration. I shall deal with the first in this section, that is: Jesus' death as an event at the centre of the world. The second - the cultic aspects of his death - will follow in section 2.5.

It is Dennis Sylva (1990b) who exploits the well-known feature of the centrality of Jerusalem in Luke-Acts for our understanding of Jesus' death. It is a well-established tenet of Lukan scholarship that Jerusalem receives much more attention in Luke-Acts than in the other Gospels. A few observations will refresh our memory. One can say that all the important soteriological events take place in Jerusalem. Luke is unique among the Gospels in restricting all the post-resurrection appearances of Jesus to Jerusalem. Furthermore, apart from the death of Jesus, that Luke takes over from the tradition, Luke is the only Gospel that presents Bethany, in the near

vicinity of Jerusalem, as the setting for the ascension (Lk 24:50). Although the other Gospels do not mention the ascension, they contain the explicit command that Jesus would appear to his disciples in Galilee (Mk 16:7; Mt 28:7,10,16). Even the Gospel of John reflects this tradition (Jn 21:1ff, 
describing the final appearances of Jesus), although John describes appearances of the resurrected Jesus in Jerusalem too (Jn 20:11-30). Subsequently Luke also places the outpouring of the Holy Spirit in Jerusalem. As a matter of fact, the disciples are instructed to remain in Jerusalem until they have received the gift of the Father (Lk 24:49; Acts 1:4). And, finally, it is from Jerusalem that the gospel spreads throughout the

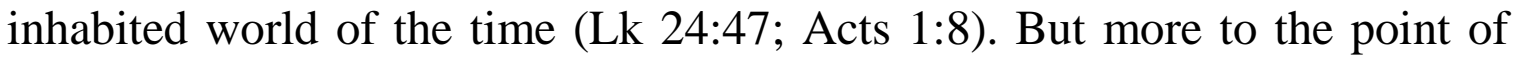
our subject, it is of great significance that Luke creates a travel narrative (Lk 9:51-19:27) in his first work that forcefully directs the reader's attention to Jerusalem as the place of Jesus' death. On three occasions the reader is reminded that Jesus had set his mind on the task that awaited Him in Jerusalem: 9:51; 13:22 and 17:11 ${ }^{19}$. In 9:51 the task is described as Jesus being "taken up", which refers to his ascension. But this "taking up" is counterbalanced on three occasions by Jesus announcing that first He was going to meet his death in Jerusalem, the first two announcements leading up to the travel narrative $(9: 22,44)$, and the third immediately before entering Jerusalem (18:32). Thus the prolonged movement towards Jerusalem created by the travel narrative (ten chapters in total!) not only ensures a mounting of suspense of something ominous in the offing, but also ties this suspense to Jerusalem.

These observations have a bearing on our understanding of the death of Jesus. They can be set against the following background. (In what follows I for the most part present Sylva's views.) The Hebrew scriptures often refer to Jerusalem as a holy place (e g Neh 11:1; Is 48:2; 52:1), a holy mountain (e g Ps 2:6; 3:5; 48:2; Is 11:9; 56:7), and the locus of God's presence and/or favour (e g Ps 46:6; 48:3; 76:3; 132:13-14;135:21; Jl 3:17; Zch 2:10-11). And the notion of Jerusalem as the centre of the world is basically present in Ez 5:5; 38:12, and probably in Is 6:1-8, but it is only during the first two centuries $\mathrm{AD}$ that the centrality of Jerusalem became a more developed concept and crops up in several Jewish writings (e g 1 En 26:1-27:5; Mishnaic Tractate Yoma 5: $2^{20}$, and JosBJ 3.52; Ant 3.7.7) (Sylva 1990b:155156). What is of equal importance is that 1 En 90:26, for one, also mentions ideas associated with Jerusalem being the centre of the world, such as the valley of the damned situated next to Jerusalem. Thus Jerusalem is seen both

${ }^{19}$ Brown (1997:244ff) uses these three reminders to divide the travel narrative into three subsections: 9:51-13:21; 13:22-17:10; and 17:11-19:27.

20 The reference is to a "foundation stone" (shetiyyah) in the holy of holies. The full translation (by Neusner 1988) runs: "A. Once the ark was taken away, there remained a stone from the days of the earlier prophets, called Shetiyyah. B. It was three fingerbreadths high. C. And on it he put [the fire pan].” 
as the pivot place of God's central rule and the location where the destiny of the wicked is decided, a hot spot so to speak of the eternal conflict between good and evil, God and the powers of darkness. The point is that these ideas about Jerusalem were circulating in Jewish theology round about the time of the composition of Luke-Acts ${ }^{21}$. Thus it may be fruitful to let this general background about the centrality of Jerusalem, together with the similar position Jerusalem occupies in Luke-Acts, have a bearing on the interpretation of Jesus' death in Jerusalem. The following line of thought may be drawn.

As was described above, Luke is the only evangelist who narrates the ascension of Jesus, or put differently, the movement of Jesus from earth to heaven, from below to above. And the point of departure of this movement is Jerusalem (cf Lk 9:51 that says Jesus is going to be "taken up"). Thus one can say there is a concern with Luke about a movement between two worlds, with Jerusalem as the earthly locus of such movement, a notion which is also supported by Pentecost where the movement is reversed (from above to below), Jerusalem again being the locus of this movement (Sylva 1990b:158). Furthermore, Luke's treatment of Satan also contributes to the idea of Jerusalem being the centre of the world, this time the centre of the struggle between God and Satan. Here we should keep in mind what has been mentioned above about the valley of the damned, described in Jewish literature as being close to Jerusalem. This should be tied to the observation that in Luke-Acts Satan's activities towards Jesus (and the church) are largely concentrated in Jerusalem. It can be demonstrated in the following way: Luke begins his linkage of Satan to Jerusalem with the temptations of Jesus in 4:1-13. Compared to Matthew, Luke changes the order of the second and third temptation so that the temptations end in Jerusalem. This emphasises Jerusalem as the locus of Satan's attacks of Jesus. But then follows a period (up to 19:44) where Jerusalem is not the locale of Jesus' activities. And this is also a conspicuous "Satan free",2 period, actually up to 21:38. But when the story continues in Jerusalem, Satan is present again. We read that he entered Judas Iscariot, one belonging to the inner circle of Jesus (22:3), that he tempts the apostles (22:31) - later a church member too, Ananias (Acts 5:3) - and that he is instrumental in the arrest of Jesus (22:53). Thus, Jerusalem is the sphere where Satan is directly present and

${ }^{21} 1$ Enoch dated $2^{\text {nd }}$ century BC to $1^{\text {st }}$ century AD by IsaActs (1983:5-7).

22 Although in this period Satan's minions, the daimonia, are active, it is not Satan in person. Satan is only mentioned in Lk 8:12; $10: 18$ and 11:15-18, but is not active, in any case not as far as Jesus is concerned. 
active. One can say that Jerusalem, the centre of the world, is the meeting place of three worlds: heaven, earth and the netherworld (the forces of evil). To summarise, Luke is the only one among the Gospels who stresses the centrality of Jerusalem: the temple in Jerusalem is a holy space so that Jesus and the leaders of the early church worship there, and Jerusalem is the special place where the movements between the worlds take place. (All Jesus' resurrection appearances are restricted to Jerusalem; the ascension is mentioned twice as taking place here; the apostles are instructed to wait here for the gift of the Father; and the Holy Spirit is poured out here.)

The meaning of all this for our subject can be summed up as follows. Jerusalem forms the epicentre of two movements. First, Jesus' death is not a mere physiological event, a fluke convergence of circumstances that spun out of control, but it is an engulfing by the destructive forces of evil. Jerusalem is the place where these forces, with Satan himself at the helm, work through Judas and the Jewish leaders to plunge Jesus into the underworld. And it happened in spite of the political might of Rome that tried to prevent it from happening by declaring Jesus innocent more than once. Through his death Jesus partakes in the chaos at the centre of the world. Not for nothing Luke is the only one describing this event as the hour of evil people and the power of darkness unleashed in all its might (Lk 22:53). Bearing this in mind, the second movement taking place in the Jerusalem area receives all the more prominence: how God rescues Jesus from this primordial chaos by raising Him from the underworld, giving Him the place of honour at his right hand, making Him Lord and Christ, and

giving Him the right to administer the giving of his Spirit to all the nations gathered at the Pentecost feast.

\subsection{Jesus' death as a memorial of expiation of sins}

The concept of the centrality of Jerusalem foregrounds the importance of the temple. In this regard Carpinelli (1999) has drawn our attention to the cultic aspects of Jesus' death in Luke. Carpinelli takes the view that the omission of Mark 10:45 (the I ut r on-saying in particular) in Luke 22:27 has clouded our eyes for another peculiarity in Luke's rendering of the Last Supper. Having reported Jesus' words: "This is my body, which is given for you”, Luke is unique in adding the phrase: tout o poieite eif t $n$ ejhn $n$ ajamnhs in ("do this in remembrance of me") (Lk 22:19). This phrase Carpinelli interprets as Jesus having set up a cultic rite, a memorial. Says Carpinelli (1999:75): "By appointing the bread rite as memorial and the cup as covenant in Jesus' blood Luke uses contemporary Jewish and JewishChristian piety to assign meaning and significance to the cross." Luke 
utilises the soteriology of memorial before God that is embedded in the rich cultic, expiatory theology of the LXX. (It is well known that the LXX serves as source for Luke's quotations.) Thus the absence of the I utron-saying does not diminish Jesus' death as expiation and atonement ${ }^{23}$; on the contrary, the remembrance-phrase in Luke 22:19 points to the death of Jesus as having soteriological meaning in itself, a view that is quite a novelty in established Lukan scholarship $^{24}$. How is this view substantiated?

When the usage of the prepositional expressions eif a amnhsi and eif mnhmosunon (the two expressions being functionally equivalent) is traced in Acts, the LXX and contemporary Jewish literature, it is shown that objects, events and gestures are signified as cultic memorials before God. Examples: In Acts 10:4 the alms and prayers of Cornelius, the God-fearer, have become memorials before God. In Sir 45:16 and Lev 24:7 incense (in the latter, bread too), and in Num 10:10 and Sir 50:16 the blast of a ram's horn are characterised as memorials. And between the testaments in Heb 10:1-3 and Num 5:15 sacrifices become memorials of sin. In the LXX and in 1 Enoch cultic objects and gestures are labelled as memorials, for example the Passover (Ex 12:14), gold (Num 31:54), atonement money (Ex 30:16), and prayers (1 En 99:3). Furthermore, in the written witnesses of first century Jewish piety examples can be found of persons giving expiatory memorials. In 1 En 14:21-25 God exalts Enoch over angels by making him draw near the throne in heaven. The watchers earlier implored Enoch to

\footnotetext{
23 To Carpinelli “expiation” and “atonement” function as synonyms. They mean what i) a s koma i and cognates mean in the LXX as translations of rpk(1999:75 fn 1).

${ }^{24}$ In any case one should be wary of making too much of the absence of the I utr on saying (Mk 10:45) in Lk 22:27. If one takes the stance that Luke followed a non-Markan source at this point, there is no suggestion of a deliberate omission of Mk 10:45 (see footnote 2). Most recently it was Baarlink (2002:26-28) who tried to demonstrate in some detail that Luke did not take over Mk 10:35-45, but made use of a unique tradition which bears closer resemblance to John and Paul than to Mark, particularly through the coupling of Last Supper and feetwashing (Jn 13), and Last Supper and parenesis (1 Cor 11). Thus in both instances the Last Supper is linked to the problem of haughtiness among some disciples / church members, precisely as we find it in Lk 22:14-30. In another argument Baarlink (2002:23-25) also shows that due to Luke's overall structural strategies, especially the way he links certain pericopes to the passion announcements (Lk 9:44 and 18:32) - which results in Mk 10:35-45 not being utilised - one should not infer from the absence of the latter pericope that Luke deliberately removed Jesus' saying about his death being a ransom for many. Baarlink regards such an inference as misleading, and detrimental to the case of Jesus' death in Luke's soteriology. Fuller (1979), comparing the statistics between Mark and Luke regarding the explicit references to the cross, more or less comes to the same conclusion.
} 
write for them memorials of prayers (1 En 13:4), so that they might have forgiveness when Enoch raised those memorials before God. And in Jubilees Noah ordains four feasts as memorials (Jub 6:17-31). Hence it is evident that divinely appointed mediators, who can provide a cultic memorial so that others may have expiation before God, are a feature of ancient Jewish piety, and thus was available to Luke as a mechanism of interpretation for Jesus' relation to God. Armed with this information, and coupled to the possessive adjective ejmh $n$ appearing in Luke 22:19, one can say that this verse depicts Jesus ordaining a cultic memorial before God. The offering of bread becomes a cultic rite in which the death of Jesus is set up as a memorial for his followers (cf the uper umwn of v19 and 20) in the presence of God. The death of Jesus becomes a means whereby Jesus' followers can "remind” God of the expiation of sins wrought by Jesus. Consequently Carpinelli translates Luke 22:19 as follows: “'Do this as my memorial', that is, as a permanent cultic means of access to God's regard which I set up for you” (1999:79).

It must be made clear, though, that Carpinelli does not regard the expiatory or atonement theology of Luke as evidence for substitutionary theology. Since Luke draws a picture of God who is more pleased than angry with Israel, Luke might have found it inappropriate to link propitiatory substitution to God's purpose in the passion of Jesus. And this might just be the reason why, according to Carpinelli, Luke did not include the I ut r onsaying of Mark 10:45, especially if Luke had understood Mark 10:45 in a substitutionary light ${ }^{25}$. But still Luke had available to him the dominant nonsubstitutionary, expiatory soteriology of his LXX source ${ }^{26}$.

25 Scholars whose views on Mk 10:45 may be taken as in support of Carpinelli's standpoint about Luke's redaction of Mk 10:45, are Pilgrim and Scheffler. Pilgrim (1971:236) takes the view that Luke deliberately has edited out the I ut r on -saying at this point because “... Luke's conception of Jesus' death does not belong within the framework of redemptive motifs." This view may be corroborated by another set of data. If we take as our point of departure that Luke used Mark as his Vorlage in compiling his passion narrative, the exclusion of the I utr on -saying may be explained by the fact that Luke wanted to place the emphasis on the service of Jesus to his followers. Thus Luke transposed the whole pericope, Mk 10:41-45 (the dispute about greatness), to the context of the institution of the Last Supper. In so doing he stressed the close relationship between Jesus' death and his humiliation in service of his followers (cf Scheffler 1993:156), underplaying the so-called redemptive meaning of Jesus' death.

26 The subject of the various kinds of soteriological meanings attached to the death of Jesus is far too complex to unravel within the ambit of this article. Suffice it to say that I have used the adjectives "soteriological", "redemptive", "salvific", "atoning", "expiatory" rather loosely, and as more or less working equivalents for viewing the death of Jesus as effecting salvation. To my mind Carpinelli's distinction between the 
Finally Carpinelli's cultic interpretation of Jesus' death opens up a range of other issues which may shed new light on traditional views about Luke's soteriology. Carpinelli's basic view is that he would like to replace the now established history of salvation view of Lukan theology with that of "cultic evolution”. It means that fundamental aspects in Lukan theology should rather be seen in terms of a (cultic) reinterpretation of Old Testament cultic themes. Asks Carpinelli (1999:89): Is it coincidental that Luke starts and ends his Gospel with worship in the temple? Why is Paul in Acts portrayed as a devotee of the temple? And why is the conflict in Luke-Acts essentially with the chief priests; on the other hand: why bother to mention that many priests embraced faith in Jesus (Acts 6:7)? It seems as if Luke is interested in Israel's history as the evolution of God's relationship with it, a relationship in which intimacy and worship are prominent. Therefore a view of Luke's theology as divine-human relations rather than salvation history may be more appropriate.

Carpinelli concludes by drawing a comparison between Sirach 50 and the way Jesus is depicted in his ascension by Luke. As Jesus ascends, Luke portrays Him giving Aaron's blessing as the high priest would after sacrifice on the Feast of Atonement. In Sirach 50 too the glory and function of the high priest on the Day of Atonement are depicted. Both in Luke 22:14-23 and in Luke 24:50-53 Jesus is pictured functioning as a priest: in Luke $22 \mathrm{He}$ officiates as priest by giving the bread as memorial and the blood as token of the new covenant in his blood, and in Luke 24 He concludes the rite by administering Aaron's blessing to his people at his ascension. The net result of this priestly portrayal of Jesus may be that Jesus is seen as the new cornerstone of the temple which the chief priests, as the builders, rejected (Acts 4:11). In this manner Jesus becomes the locale where the new relationship between God and his people, as well as the worship of God, should take place. Not the temple, but Jesus is the new meeting place of God and humans ${ }^{27}$, a notion present in the Fourth Gospel too (Jn 2:21; cf 1:14;

substitutionary and expiatory meaning of Jesus' death is unsatisfactory. If by "substitutionary" is meant "vicarious", it is difficult to see how expiation can be excluded from that. At least in common usage these two terms point to the same thing: the forgiveness of sins wrought by the vicarious death of Jesus. But since this is not the topic of this article, I let the matter rest. But the reader should know that as far as this article is concerned, I do not attach a specific theory of salvation to the death of Jesus.

${ }^{27}$ In this regard, note Green's investigation (1991) into the rending of the temple veil in Luke. He comes to the conclusion that it functions as a symbol for the undermining of the holiness-purity matrix embodied in the temple. Matera (1985:472-475) concentrates more on the position in the order of events the rending of the temple curtain occupies in Luke 


\section{4:19-24) (cf Brown 1971:33-34,124).}

For our subject - how Luke portrays the death of Jesus - the outcome of Carpinelli's study is significant: Jesus' death has soteriological meaning in itself. It does not only have indirect or provisional meaning; it does not first obtain meaning when viewed in retrospect from the exaltation of Jesus, but in and of itself it plays an important and independent role in the soteriology of Luke ${ }^{28}$. It acquires the meaning of a memorial before God of expiation of sins, ordained by Jesus as priest.

\section{SUMMARY AND APPRAISAL}

All that remains for me is to sum up the salient points put forward by each of the perspectives surveyed above, and to give a brief, general appraisal.

Despite the low-keyed interpretation the death of Jesus traditionally has received in Lukan scholarship, there can be no doubt about the prominent place it occupies in Luke-Acts in terms of the statements made about it. These statements unequivocally assign to Jesus' death a place of divine necessity in God's salvation plan, although at first glance it is not always clear what exactly this means.

In the exaltation of Jesus - resurrection, ascension, sitting at the right hand of God, and his administering the gift of the Holy Spirit - God clearly shows that He has vindicated Jesus' death. Although people rejected Jesus,

vis-à-vis Mark: not after Jesus died (Mark), but before He died. From this Matera infers that Luke wants to signal that it is not yet the end for the temple, as can be inferred from Mark's rendition. Yes, the days of the temple are counted, but it still has a positive role to play in Acts. Thus both Green and Matera acknowledge that the rending of the temple veil marks the beginning of the end of the central position the temple occupied in the religious life of Israel. The shift is irreversible towards the new experience of God in the risen Jesus.

${ }^{28}$ Moessner (1989:322-324) comes to the same conclusion, but from a different angle. He understands the Lukan travel narrative (Lk 9:51-19:44) as modelled after the Deuteronomistic exodus motif, according to which Moses had to die in order to deliver his people from their sinful stubbornness during their exodus to the promised land. Likewise Jesus took his journey to Jerusalem (= suffering and death) upon Him as a divine necessity (Lk 9:51; 13:33). Also, the adding of the Last Supper tradition to the travel narrative enhances the representative character of Jesus' death. This combined narrative signals that the suffering and death of Jesus cannot be a mere prelude to the real locale of salvation, the resurrection. It receives too much emphasis in Luke. The death of Jesus, therefore, is not a mere appendix to the resurrection, but has independent meaning in itself. For Luke there can be no forgiveness of sins without Jesus' death. (See also Moessner 1993 how he links the atoning suffering and death of Moses to Jesus in terms of Luke-Acts .) 
and the Jewish leaders killed Him, God has made Him Lord and Christ. Through the resurrection and the outpouring of the Spirit, Jesus has acquired an abiding place in the midst of his church. And so the joy has returned. In light of the obvious emphasis on the resurrection in Luke-Acts, Lukan scholarship tends to attribute a minor place to the death of Jesus, at most that of an admittedly necessary but nevertheless preliminary stage in the big salvation history scheme of Lukan theology. The point is that in this scheme Jesus' death does not have soteriological meaning in itself.

Taking their cue from this low-keyed interpretation of Jesus' death, scholars have tried to interpret the death of Jesus in terms of martyrdom, along the same lines as the death of the Jewish martyrs in the history of Israel. Luke-Acts stresses the point that Jesus was killed innocently. As such Jesus' death acquires the meaning of moving people (especially the Jews) to repentance, and of setting an example to Christian believers of how to behave in similar circumstances of persecution. However, scholarship has shown the deficiencies of this category of interpretation, and has moved to other categories, such as viewing Jesus' suffering as that of a righteous man, and, more particularly, interpreting it in terms of the Lord's suffering Servant of Is 52-53. As such the aspects of rejection and vindication are highlighted, and applied to Jesus they serve to keep in balance and in tension both the moments of his crucifixion and exaltation. This interpretation also fits in well with Luke's overall notion of the reversal of roles, in which the mighty and the powerful are brought to a fall, and the lowly are elevated to God's favour.

Another way of zooming in on the significance of Jesus' death as such is to view it from the perspective of the centrality of Jerusalem in Luke's theology. Jerusalem is both the centre of God's mighty redemptive work resurrection, ascension and outpouring of the Holy Spirit - and the centre of Satan's attacks on Jesus. Thus Jerusalem represents two movements in connection with Jesus: descent into the underworld and ascent into heaven, the latter with its corollary: the movement of the Spirit from heaven to earth. Hence one can see the death of Jesus as partaking in the chaos at the centre of the world, as well as being rescued by God from this primordial chaos. This view boils down to more or less the same as what has been said about Jesus being portrayed as the Lord's Servant: it keeps two movements in tension - crucifixion and exaltation.

The last perspective on Jesus' death treated above, likewise - broadly speaking - takes its cue from the centrality of Jerusalem, but concentrates on the temple and consequently the cultic implications of Jesus' death. 
Carpinelli is the proponent of this view and sees Jesus' death as a memorial before God of the expiation of sins. The key to this understanding is the phrase: "do this in remembrance of me" (Lk 22:19). With this interpretation Jesus' death obtains a soteriological meaning in itself, and not first when seen in unison with his exaltation, as Lukan scholarship has done until now.

In appraisal of the above possibilities of viewing the death of Jesus in Luke-Acts, there seems to be a discernible tendency in Lukan scholarship to move away from a bland underestimation of Jesus' death towards a more balanced view. With "balanced" I mean that the Lukan writings are being scrutinised to discover layers of meaning that more positively evaluate the soteriological meaning of Jesus' death in itself. We may regard Carpinelli's effort to highlight the expiatory meaning of Jesus' death as too daring and adventurous, but the data he put forward cannot be ignored and will have to be given serious consideration. But even if these results are not accepted in toto, the other studies accentuating the death of Jesus as that of a righteous man and as Servant of the Lord are too solid to be ignored. Granted, it is not as if these studies all of a sudden upset the applecart of Lukan scholarship that stresses the exaltation of Jesus as the zenith of Lukan soteriology. Admittedly the soteriological meaning of Jesus' death in the Lukan writings is not that conspicuous at first glance. But having fine-tuned our investigations into this matter, it has become clear that there is a growing tendency to assign to Jesus' death a more positive soteriological meaning in and of itself.

\section{Consulted literature}

Baarlink, H 2002. Jezus als dienaar (Lc 22,27) of als verzoener (Mc 10,45)? Een exegetische speurtocht door het evangelie naar Lucas. Gereformeerd Theologisch Tijdschrift 102, 16-28.

Becker, J 1990. Die neutestamentliche Rede vom Sühnetod Jesu. Zeitschrift für Theologie und Kirche, Beiheft 8, 29-49.

Bellinger, W H \& Farmer, W R (eds) 1998. Jesus and the Suffering Servant. Harrisburg: Trinity Press International.

Brown, R E 1971. The gospel according to John. I-XII. London: Geoffrey Chapman. (Anchor Bible.)

Brown, R E 1997. An introduction to the New Testament. New York: Doubleday.

Carlson, R P 1991. The role of the Jewish people in Luke's passion theology, in Lovering 1991:82-102.

Carpinelli, F G 1999. “Do this as my memorial” (Luke 22:19): Lucan soteriology of atonement. Catholic Biblical Quarterly 61, 74-91.

Carroll, J T \& Green, J B 1995 (ed). The death of Jesus in early Christianity. Peabody: Hendrickson.

Carroll, J T 1990. Luke's crucifixion scene, in Sylva 1990a:108-124. 
Chance, J B 1991. The Jewish people and the death of Jesus in Luke-Acts : Some implications of an inconsistent narrative role, in Lovering 1991:50-81.

Decock, P B 1981. The understanding of Isaiah 53:7-8 in Acts 8:32-33. Neotestamentica 14, 111-133.

Du Plessis, I J 1994. The saving significance of Jesus and his death on the cross in Luke's Gospel - focussing on Luke 22:19b-20. Neotestamentica 28, 523-540.

Durken, D (ed) 1979. Sin, salvation and the Spirit. Collegeville: Liturgical Press.

Ehrman, B D 1991. The cup, the bread and the salvific effect of Jesus' death in LukeActs, in Lovering 1991:576-591

Fuller, R H 1979. Luke and the theologia crucis, in Durken 1979:214-220.

Goppelt, L 1978. Theologie des Neuen Testaments. 3. Auflage. Göttingen: Vandenhoeck.

Green, J B 1988. The death of Jesus. Tübingen: Mohr (Paul Siebeck). (WUNT 2.Reihe 33.)

Green, J B 1990. The death of Jesus, God's servant, in Sylva 1990a:1-28.

Green, J B 1991. The death of Jesus and the rending of the temple veil (Luke 23:44-49): A window into Luke's understanding of Jesus and the temple, in Lovering 1991:543-557.

Green, J B 1992. Death of Jesus, in Green, J B, McKnight, S, \& Marshall, I H (eds). Dictionary of Jesus and the Gospels. Leicester: InterVarsity Press.

Grundmann, W 1969. Das Evangelium nach Lukas. Berlin: Evangelische Verlagsanstalt. (ThHNT 3.)

Herrick, G 1997. The atonement in Lucan theology in recent discussion. Biblical Studies Press. (http://www.bible.org)

Hooker, M D 1998. Did the use of Isaiah 53 to interpret his mission begin with Jesus? in Bellinger \& Farmer 1998:88-103.

Isaac, E 1983. 1 (Ethiopic Apocalypse of) Enoch, in Charlesworth, J H (ed), The Old Testament Pseudepigrapha. Volume 1: Apocalyptic Literature and Testaments. London: Darton, Longman \& Todd.

Jones, D L 1984. The title “servant” in Luke-Acts, in Talbert 1984b:148-165.

Karris, R J 1990. Luke 23:47 and the Lukan view of Jesus' death, in Sylva 1990a:68-78.

Kodell, J 1979. Luke's theology of the death of Jesus, in Durken 1979:221-230.

Lohse, E 1963. Märtyrer und Gottesknecht. Untersuchungen zur urchristlichen Verkündigung vom Sühntod Jesu Christi. 2.Aufl. Göttingen: Vandenhoeck.

Lovering, E H (ed) 1991. Society of Biblical Literature 1991 Seminar Papers. Atlanta: Scholars.

Marcus, J 1995. The Old Testament and the death of Jesus: The role of Scripture in the Gospel passion narratives, in Carroll \& Green 1995:205-233.

Matera, F J 1985. The death of Jesus according to Luke: A question of sources. Catholic Biblical Quarterly 47, 469-485.

Metzger, B M 1975. A textual commentary on the New Testament. A companion volume to the United Bible Societies' Greek New Testament $\left(3^{\text {rd }}\right.$ ed). Corrected edition. New York: UBS.

Moessner, D P 1989. Lord of the banquet. The literary and theological significance of the Lukan travel narrative. Minneapolis: Fortress. 
Moessner, D P 1993. Suffering, intercession and eschatological atonement: An uncommon view in the Testament of Moses and in Luke-Acts, in Charlesworth, $\mathrm{J}$ H \& Evans, C A (eds), The Pseudepigrapha and early Biblical interpretation, 202-227. Sheffield: Sheffield Academic Press. (Journal for the Study of the Pseudepigrapha. Supplement Series 14.)

Neusner, J 1988. The Mishnah. A new translation. New Haven: Yale University Press.

O'Toole, R F 2000. How does Luke portray Jesus as Servant of YHWH. Biblica 81, 328346.

Parsons, M C 1998. Isaiah 53 in Acts 8. A reply to professor Morna Hooker, in Bellinger \& Farmer 1998:104-119.

Pilgrim, W E 1971. The death of Christ in Lukan soteriology. Th D dissertation, Princeton Theological Seminary. (Ann Arbor: University Microfilms.)

Richard, E 1990. Jesus' passion and death in Acts, in Sylva 1990a:125-152.

Ruppert, L 1989. Der leidende Gerechte, in Van Henten 1989b:76-87.

Scheffler, E 1993. Suffering in Luke's Gospel. Zürich: Theologischer Verlag. (AThANT 81.)

Sylva, D D 1990a (ed). Reimaging the death of the Lukan Jesus. Frankfurt am Main: Hain. (Athenäum Monografien, Theologie, Bonner Biblische Beiträge. Band 73.)

Sylva, D D 1990b. Death and life at the center of the world, in Sylva 1990a:153-169.

Talbert, C H 1984a. Promise and fulfillment in Lucan theology, in Talbert 1984b:91-103.

Talbert, C H (ed) 1984b. Luke-Acts . New perspectives from the Society of Biblical Literature Seminar. New York: Crossroad.

Tiede, D L 1991. Contending with God: The death of Jesus and the trial of Israel in LukeActs, in Pearson, B A (ed), The future of early Christianity. (FS Helmuth Koester.) Minneapolis: Fortress.

Tyson, J B 1986. The death of Jesus in Luke-Acts . Columbia: University of South Carolina Press.

Van der Kooi, C 1997. Dankzij of ondanks de dood van Jezus? Nederlands Theologisch Tijdschrift 51, 281-297.

Van Henten, J W 1989a. Das jüdische Selbstverständnis in den ältesten Martyrien, in Van Henten 1989b:127-161.

Van Henten, J W (Hrsg) 1989b. Die Entstehung der jüdischen Martyrologie. Leiden: Brill.

Williams, S K 1975. Jesus' death as saving event. The background and origin of a concept. Missoula: Scholars. 